\title{
KEANEKARAGAMAN JENIS DAN DISTRIUSI FITOPLANKTON SECARA VERTIKAL DI PERAIRAN PULAU BOKORI
}

\author{
Vertical Diversity of Types and Distribution of Phytoplankton \\ in Bokori Island Waters
}

\author{
Reny W.A Lolo Padang ${ }^{1}$, Wa Nurgayah ${ }^{2}$, Nur Irawati ${ }^{3}$ \\ ${ }^{1}$ Mahasiswa Jurusan Ilmu Kelautan, \\ Fakultas Perikanan dan Ilmu Kelautan, Universitas Halu Oleo. \\ Jl. H.E.A Mokodompit Kampus Hijau Bumi Tridharma Anduonohu Kendari 93232, Telp/Fax: (0401) 3193782 \\ ${ }^{2}$ Surel: nurgayah_fish@yahoo.com \\ ${ }^{3}$ Surel: nur_irawati@gmail.com
}

\begin{abstract}
Abstrak
Fitoplankton organisme yang berperan sebagai produsen primer di perairan laut, baik secara langsung maupun tidak langsung mendukung kehidupan organisme laut. Komposisi maupun kelimpahan fitoplankton sangat berpengaruh terhadap keberadaan sumber daya hayati laut lainnya di perairan. Penelitian ini bertujuan untuk mengetahui keanekaragaman jenis dan distribusi fitoplankton secara vertikal di perairan Pulau Bokori. Pengambilan sampel fitoplankton dilakukan selama 6 minggu dengan interval waktu pengambilan sampel dua minggu sekali dari bulan Desember 2018 sampai Januari 2019. Variable utama dalam penelitian ini adalah keanekaragaman dan distribusi fitoplankton, sedangkan variable pendukung adalah parameter fisika dan kimia yang diukur langsung dari tempat penelitian dan laboratorium. Sampel fitoplankton disaring menggunakan jarring plankton ukuran $25 \mu$ m. pengambilan sampel dengan metode purposive sampling, yaitu pada masing-masing stasiun terbagi dalam 3 variasi kedalaman yaitu 0,5, 5 dan 10 meter. Hasil penelitian menunjukkan komposisi jenis fitoplankton yang ditemukan di Perairan Pulau Bokori berjumlah 4 kelas yaitu terdiri dari kelas Bacillariophycea (11 genera), kelas Dinophyceae (4 genera), kelas Cyanophyceae dan Coscinodiscophyceae masing-masing terdiri dari 1 genus. Kelimpahan fitoplankton berkisar 185-1601 ind/L. kelimpahan fitoplankton didominasi kelas Bacillariophyceae (Chetoceros sp). Kelimpahan tertinggi fitoplankton terdapat pada stasiun III kedalaman 0,5 meter. Sedangkan kelimpahan terendah fitoplankton stasiun II pada kedalaman 5 meter. Keanekaragaman fitoplankton pada perairan Pulau Bokori termasuk rendah dan pola distribusi fitoplankton di perairan Pulau Bokori yaitu mengelompok.
\end{abstract}

Kata Kunci : fitoplankton, kedalaman berbeda, Pulau Bokori

\begin{abstract}
Phytoplankton is the primary producer which is support a marine organism live. The composition and abundance of phytoplankton greatly influences to the presence of other marine biological resources in ecosystem. This study aimed to determine species diversity and distribution of phytoplankton vertically in Bokori Isle. Sampling was carried out for 6 weeks with two weeks of interval time from December 2018 to January 2019. Two main variables in this study were the diversity and distribution of phytoplankton, while the supporting variables were physical and chemical oceanography through insitu and laboratory analysis. Phytoplankton samples were filtered using $25 \mu \mathrm{m}$ of plankton nets. Purposive sampling method was used and divided into 3 depth variations, namely $0.5,5$ and $10 \mathrm{~m}$ at each station. Four classes of phytoplankton were found at the study area consisting of Bacillariophycea (11 genera), Dinophyceae (4 genera), Cyanophyceae and Coscinodiscophyceae classes with 1 genus for each class. The abundance of phytoplankton ranged from 185 to 1601 ind / L. The abundance of phytoplankton was dominated by the Bacillariophyceae (Chetoceros sp) class. The highest abundance of phytoplankton was found at station III at a depth of $0.5 \mathrm{~m}$, while the lowest abundance was found at station II at a depth of $5 \mathrm{~m}$. The diversity of phytoplankton was in low category with grouped distribution pattern.
\end{abstract}

Keywords: phytoplankton, composition, abundance, depth variations, Bokori Island

\section{Pendahuluan}

Fitoplankton tergolong ke dalam organisme autotrof karena mampu menghasilkan senyawa organik dengan memanfaatkan energi karbon dari $\mathrm{CO} 2$ dan bantuan cahaya melalui proses fotosintesis, sehingga fitoplankton berperan sebagai produsen primer di suatu perairan (Yeanny, 2011).
Keanekaragaman jenis fitoplankton dipengaruhi oleh berbagai faktor lingkungan, salah satunya adalah intensitas cahaya dan nutiren. Maka dari itu diduga bahwa semakin dalam suatu perairan maka intensitas cahaya yang ada dalam perairan akan semakin menurun yang akan mempengaruhi 
keanekaragaman jenis fitoplankton. Distribusi fitoplankton dipengaruhi oleh ketersediaan cahaya dalam perairan. Secara temporal intensitas cahaya matahari yang jatuh di permukaan laut akan terdistribusi mengikuti kedalaman dan menyebabkan variabilitas intensitas cahaya matahari di kolom perairan. Perbedaan ini menyebabkan kelimpahan fitoplankton sebagai produsen utama dalam rantai makanan juga bervariasi di setiap kedalaman, mengingat pentingnya fitoplankton dalam rantai makanan di ekosistem perairan.

\section{Bahan dan Metode}

Pengambilan data dilaksanakan pada bulan Desember 2018 sampai Januari 2019 di Perairan Bokori, analisis sampel dilakukan di Laboratorium Pengujian Fakultas Perikanan dan Ilmu Kelautan, Universitas Halu Oleo, Kendari.

Survei pendahuluan dilakukan untuk mengetahui kondisi lokasi penelitian, penentuan titik stasiun penelitian, dan persiapan peralatan yang akan digunakan. Penentuan stasiun penelitian dilakukan dengan metode purposive sampling merupakan suatu metode yang digunakan untuk menemukan stasiun dengan memerhatikan kondisi pada daerah penelitian yang dapat mewakili kondisi perairan.

Stasiun I, terletak di bagian selatan Pulau Bokori, daerah ini berhadapan langsung dengan vegetasi lamun, berada pada titik koordinat $3^{\circ} 56^{\prime} 38.17^{\prime \prime}$ LS dan $122^{\circ}$ 39' 38.46" BT. Stasiun II, terletak di bagian Timur Pulau Bokori, daerah ini berhadapan langsung dengan vegetasi mangrove serta kurangnya aktivitas di daerah ini, berada pada titik koordinat $3^{\circ} 56^{\prime} 17,89^{\prime}$ ' LS dan $122^{\circ} 39^{\prime} 42,58^{\prime}$ ' BT. Stasiun III, terletak di bagian Utara Pulau Bokori, daerah ini padat akan aktivitas masyarakat lokal dan wisatawan, dengan tipe substrat berpasir, berada pada titik koordinat $3^{\circ} 56^{\prime} 15,67^{\prime \prime} \mathrm{LS}$ dan $122^{\circ} 39^{\prime} 45^{\prime \prime}$ BT.

Pengambilan sampel fitoplankton dan kualitas air secara vertikal ditentukan berdasarkan tingkat kedalaman perairan dengan mempertimbangkan intensitas cahaya matahari. Pengukuran sampel secara vertikal ini dimaksudkan untuk mengetahui distribusi intensitas cahaya yang semakin berkurang dengan bertambahnya kedalaman. Kedalaman pada setiap stasiun dibagi atas tiga kedalaman yaitu $0.5,5$ dan 10 meter yang bertujuan untuk mengetahui keragaman fitoplankton seiring dengan bertambanya kedalaman.

Pengukuran intensitas cahaya dilakukan dengan menggunakan Luxmeter yang dilakukan setiap 1 jam sekali yang dimulai pada pukul 09.00 sampai 16.00 WITA. Prinsip kerja alat ini adalah menangkap energi cahaya melalui sensor berupa photo electic cell dan merubahnya menjadi sinyal yang terbaca melalui lux selector. Nilai intensitas cahaya yang berada pada lapisan permukaan perairan, diperoleh dengan mengurangi nilai intensitas cahaya di daratan sebesar $10 \%$ dengan asumsi bahwa intensitas cahaya mengalami refleksi oleh permukaan air laut (Krik, 1994).

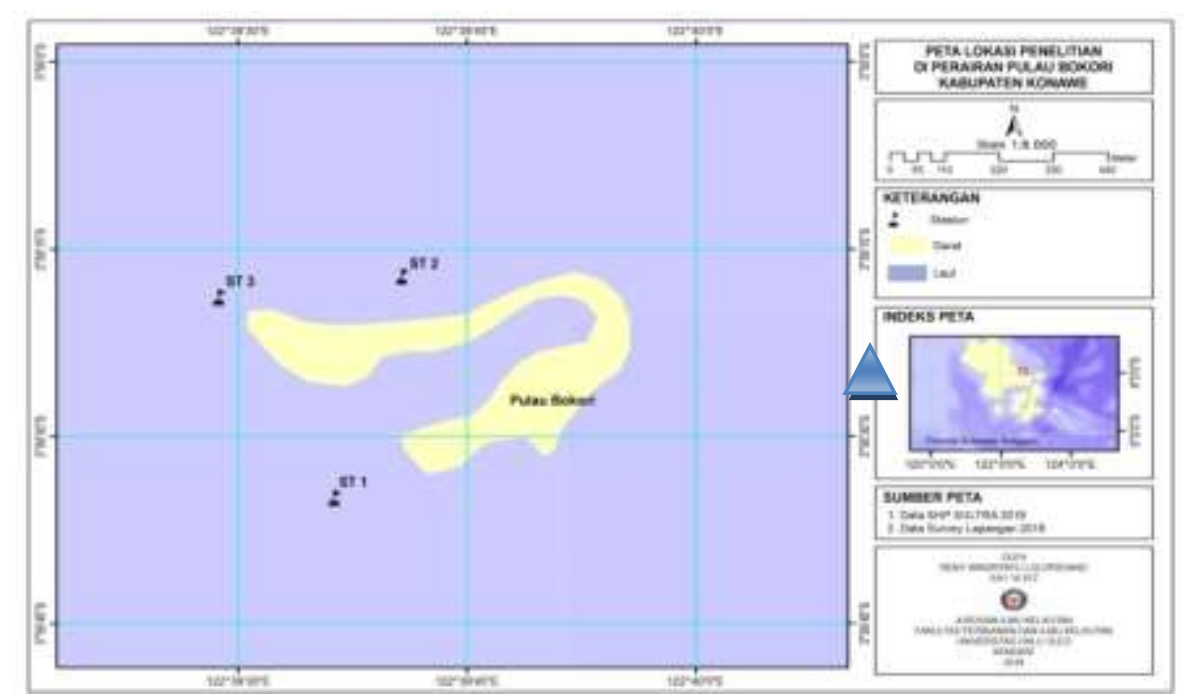

Gambar 1. Peta lokasi penelitian di Pulau Bokori 
Pengambilan sampel fitoplankton dilakukan selama 6 minggu dengan interval waktu pengambilan sampel dua minggu sekali menggunakan plankton net berukuran $25 \mu \mathrm{m}$. Pengambilan sampel fitoplankton dilakukan pada tiga stasiun dengan kedalaman yang berbeda.

Sampel fitoplankton diambil dengan cara menyaring air yang diambil disetiap kedalaman dengan menggunakan pompa air yang disambungkan dengan pipa atau selang yang kemudian diturunkan di kedalaman yang telah ditentukan dengan mengambil sampel air sebanyak 100 liter menggunakan ember. Sampel tersebut disaring menggunakan plankton net dengan ukuran $25 \mu \mathrm{m}$, sampel air yang tersaring dimasukkan kedalam botol sampel volume $30 \mathrm{ml}$ dan diawetkan dengan menggunakan pengawet Formalin 4\% sebanyak $3-5$ tetes. Saat analisis, sampel air diambil sebanyak $1 \mathrm{ml}$ menggunakan pipet tetes kemudian diamati dengan menggunakan mikroskop dengan pembesaran 100x dan diidentifikasi menggunakan buku identifikasi plankton online oleh Patten, et al. (2010).

Parameter fisika kimia perairan yang dianalisis, terdiri dari parameter fisika kimia yang dianalisis secara langsung di lapangan dan di laboratorium. Pengukuran parameter fisika dan kimia perairan dilakukan dengan mengambil sampel air pada masing-masing stasiun. Parameter yang diukur langsung di lapangan meliputi, pengukuran suhu dilakukan dengan menggunakan termometer. Pengukuran kecerahan dan kecepatan arus dilakukan di atas kapal dengan cara menurunkan layangan arus dan secchi disk ke perairan kemudian mencatat hasil yang didapatkan.

Pengambilan sampel air untuk analisis parameter kimia menggunakan botol sampel dengan volume $100 \mathrm{ml}$. Sampel air diperoleh dengan mengambil air pada setiap kedalaman yang telah ditentukan dari setiap titik stasiun, pengambilan sampel air di perairan menggunakan pompa untuk masing-masing stasiun pengamatan. Sampel air yang sudah diambil kemudian dimasukkan kedalam botol sampel ukuran $100 \mathrm{ml}$ dan diawetkan dengan menggunakan $\mathrm{H}_{2} \mathrm{SO}_{4}$ pekat sebanyak $0,5 \mathrm{ml}$ atau sekitar 10 tetes sampai $\mathrm{pH} 2$ untuk analisis parameter nitrat, sedangkan untuk parameter phospat, sampel air disaring menggunakan kertas saring. Selanjutnya sampel air dimasukkan ke dalam ice box untuk kemudian dibawah ke laboratorium dan disimpan di dalam freezer untuk di analisis, sampel air setelah dikeluarkan dari freezer dibiarkan terlebih dahulu sampai kondisi suhunya normal pada suhu kamar antara 26 $28^{\circ} \mathrm{C}$. Parameter yang diukur di laboratorium, meliputi Ortophosfat $\left(\mathrm{PO}_{4}\right)$, Nitrat $\left(\mathrm{NO}_{3}\right)$ dan Amoniak ( $\left.\mathrm{NH}_{3}\right)$. Pengukuran sampel Ortophospat menggunakan metode Amonium molybdate.

\section{Analisis Data}

Komposisi jenis fitoplankton pada masing-masing stasiun dihitung dengan menggunakan rumus Odum (1996), yaitu:

$\mathrm{Pi}=\frac{n i}{N} \times 100$

Keterangan:

$\mathrm{Pi}=$ Komposisi jenis $(\%)$

$\mathrm{ni}=$ Jumlah jenis ke-i

$\mathrm{N}=$ Jumlah total jenis

Kelimpahan fitoplankton dihitung dengan metode sensus atau sapuan dengan Sedwick Rafter Cell (SRC) menggunakan formula dari APHA (2005), yaitu:

$\mathrm{K}=\mathrm{N} / \mathrm{Ac} \times \mathrm{At} / \mathrm{Vs} \times \mathrm{Vt} / \mathrm{As}$

Keterangan :

$\mathrm{K}=$ Kelimpahan plankton (ind $\mathrm{I}^{-1}$ )

$\mathrm{N}=$ Jumlah plankton yang diamati

$\mathrm{Ac}=$ Luas amatan $\left(\mathrm{mm}^{2}\right)$

At $=$ Luas penampang permukaan $\mathrm{SRC}\left(\mathrm{mm}^{2}\right)$

$\mathrm{Vs}=$ Volume konsentratdalam SRC $(\mathrm{ml})$

$\mathrm{Vt}=$ Volume konsentrat botolcontoh plankton (ml)

As $=$ Volume air disaring $(\mathrm{L})$

Analisis yang digunakan untuk mengetahui keanekaragaman jenis biota perairan. Persamaan yang digunakan untuk menghitung indeks ini adalah persamaan Shannon-Wienner ( Handayani, 2009) yaitu:

$\mathrm{H}^{\prime}=-\sum$ pi ln pi

Keterangan :

$\mathrm{H}^{\prime}$ = Indeks keanekaragaman

$\mathrm{Ni}=$ Jumlah individu jenis ke- $\mathrm{i}$

$\mathrm{Pi}=\mathrm{ni} / \mathrm{N}$

$\mathrm{N}=$ Jumlah total individu

Kisaran indeks keanekaragamn SahnnonWienner dapat dikategorikan sebagai berikut: $\mathrm{H}^{\prime}<1=$ keanekaragaman rendah dan kestabilan komunitas rendah

$1<\mathrm{H}^{\prime}<=$ keanekaragaman sedang dan kestabilan komunitas sedang

$\mathrm{H}^{\prime}>3=$ keanekaragamn tinggi dan kestabilan komunitas tinggi 
Siagian (2012) menyatakan bahwa jika nilai indeks keanekaragaman fitoplankton pada suatu komunitas rendah maka kelimpahan fitoplankton semakin menurun, karena keanekaragaman organisme ditentukan oleh jumlah jenis dan jumlah individu dalam suatu komunitas.

Indeks keseragaman fitoplankton dihitung dengan rumus dari Odum (1998), yaitu :

$\mathrm{E}=\frac{\mathrm{H}^{\prime}}{\mathrm{H}^{\prime} \mathrm{maks}}$

Keterangan:

$\mathrm{E}=$ Indeks keseragaman

$\mathrm{H}^{\prime}=$ Indeks keanekaragaman

$\mathrm{H}^{\prime}$ maks $=1 \mathrm{n} \mathrm{S}$ ( $\mathrm{S}=$ Jumlah spesies yang ditemukan)

$\mathrm{S}=$ Jumlah spesies yang ditemukan

Menurut Pirzan et al. (2005), ketika

nilai indeks keseragaman mendekati nol berarti keseragaman antar spesies didalam komunitas tergolong rendah dan sebaliknya ketika nilai indeks keseragaman mendekati satu dapat dikatakan keseragaman antar spesies tergolong merata atau sama. Fahrul (2007) mengemukakan bahwa nilai indeks keseragaman berkisar $0-1$. Jika indeks keseragaman mendekati $1 \quad(>0,5)$ berarti keseragaman organisme dalam suatu perairan berada dalam keadaan seimbang, berarti tidak terjadi persaingan baik terhadap tempat maupun terhadap makanan, sebaliknya jika indeks keseragaman mendekati $0 \quad(<0,5)$. Menurut Siagian (2012), terjadinya perbedaan nilai indeks keseragaman pada setiap stasiun dapat terjadi karena jumlah jenis dan kelimpahan jenis masing-masing fitoplankton berbeda sehingga akan mempengaruhi nilai indeks keseragaman.

Indeks dominansi digunakan untuk melihat ada tidaknya suatu jenis tertentu yang mendominasi dalam sutu jenis populasi. Perhitungan indeks dominasi Simpson (Odum, 1998), yaitu :

$\mathrm{C}=\sum(\mathrm{ni} / \mathrm{N})^{2}$

Keterangan:

$\mathrm{C}=$ Indeks dominansi simpson

$\mathrm{ni}=$ Jumlah individu jenis ke-i

$\mathrm{N}=$ Jumlah total individu

Indeks dominansi berkisar $0-1$, bila indeks dominansi (C) mendekati 0 berarti dalam struktur komunitas biota yang diamati tidak terdapat spesies yang secara ekstrim mendominasi spesies lainnya dan bila nilainilai indeks dominansi (C) mendekati 1 berarti di dalam struktur komunitas yang sedang diamati dijumpai spesies yang mendominasi spesies lainnya (Odum, 1996).

Untuk pola distribusi fitoplankton dihitung menggunakan indeks morisita menurut Brower dan Ende (1990) dengan rumus:

$\mathrm{Id}=\mathrm{n} \frac{\sum \mathrm{X}^{2}-\mathrm{N}}{\mathrm{N}(\mathrm{N}-1)}$

Keterangan:

Id = Indeks morisita

$\mathrm{X}^{2}=$ Jumlah individu pada tiap stasiun

$\mathrm{n}=$ Jumlah stasiun

$\mathrm{N}=$ Jumlah total individu

Tabel 2. Kriteria Distribusi (Id) (Brower dan Ende, 1990)

\begin{tabular}{cl}
\hline Kisaran & \multicolumn{1}{c}{ Kriteria } \\
\hline $\mathrm{Id}=1,0$ & $\begin{array}{l}\text { Pola penyebaran individu } \\
\text { acak }\end{array}$ \\
$\mathrm{Id}<1,0$ & $\begin{array}{l}\text { Pola penyebaran individu } \\
\text { seragam }\end{array}$ \\
$\mathrm{Id}>1,0$ & $\begin{array}{l}\text { Pola sebaran individu } \\
\text { mengelompok }\end{array}$ \\
\hline
\end{tabular}

\section{Hasil dan Pembahasaan}

Komposisi jenis fitoplankton berdasarkan kelas yang ditemukan selama penelitian (Gambar 2, 3 dan 4) terdiri dari 4 kelas yakni Bacillariophyceae dengan presentase $66 \%$ pada stasiun I, 69\% pada stasiun II dan $65 \%$ pada stasiun III. Kelas Dinophyceae dengan presentase $20 \%$ pada stasiun I, $19 \%$ pada stasiun II dan $23 \%$ pada stasiun III. Sedangkan kelas Cyanophyceae dan Coscinodiscophyceae memiliki presentase nilai yang sama yakni presentase $7 \%$ pada stasiun I, 6\% pada stasiun II dan III. Berdasarkan hasil penelitian terlihat bahwa kelas Bacillariophyceae banyak ditemukan pada perairan Pulau Bokori dengan presentase $66 \%$ pada stasiun I, 69\% pada stasiun II dan $65 \%$ pada stasiun III sedangkan untuk komposisi terendah salah satunya dari kelas Cyanophyceae dengan presentase $7 \%$ pada stasiun I dan $6 \%$ pada stasiun II dan III. Hal ini sesuai dengan pernyataan Nontji (2008) mengemukakan bahwa diatom merupakan jenis dari golongan fitoplankton yang paling umum dijumpai di laut. Hal ini sesuai dengan hasil yang didapat di perairan Pulau Bokori pada waktu siang hari kelimpahahn yang paling banyak dijumpai adalah kelas Bacillariophyceae. Hal tersebut ditambahkan lagi dengan pendapat Madinawati (2010) 
bahwa kelompok plankton pada kelas Bacillariophyceae bersifat fototaksis positif sehingga pada siang hari komposisinya cenderung lebih tinggi.

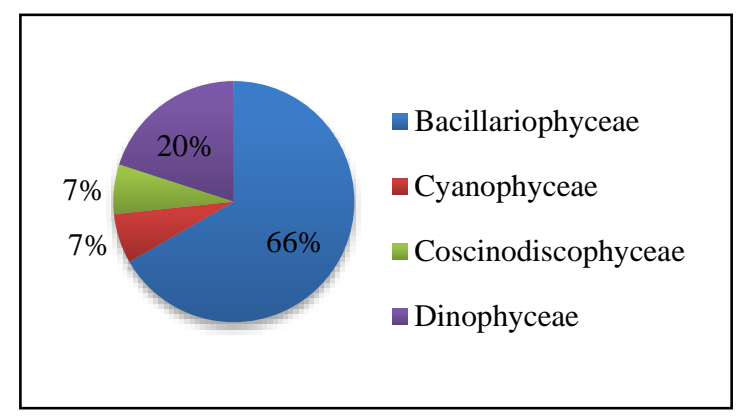

Gambar 2. Komposisi Jenis Fitoplankton Stasiun I berdasarkan family

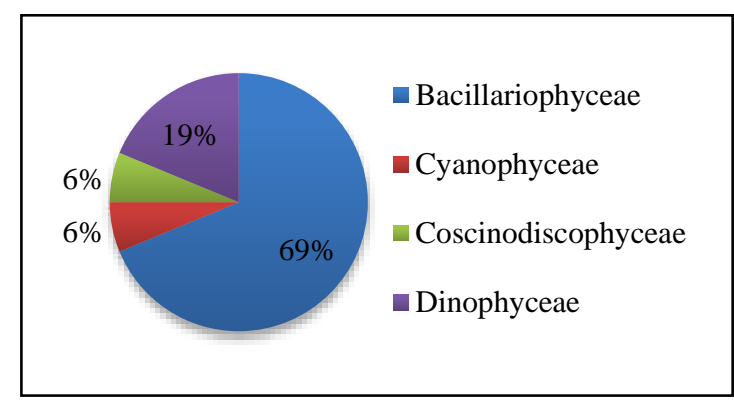

Gambar 3. Komposisi Jenis Fitoplankton Stasiun II berdasarkan family

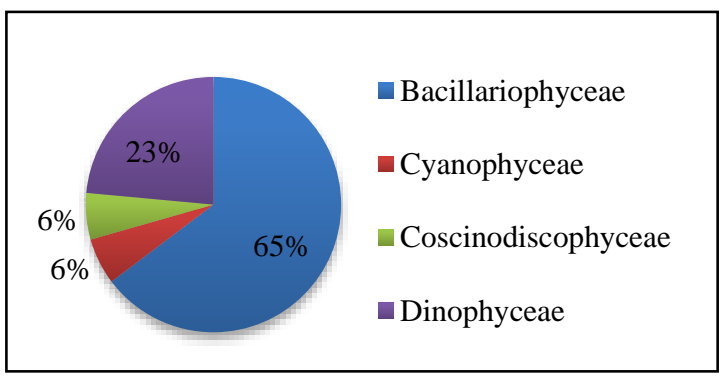

Gambar 4. Komposisi Jenis Fitoplankton Stasiun III berdasarkan family

Jenis fitoplankton yang memiliki komposisi tertinggi pada ketiga stasiun penelitian ialah spesies Chaetoceros sp. Dari kelas Bacillariophyceae, ini disebabkan karena kelas Bacillariophyceae mampu menyesuaikan dengan kondisi lingkungan yang ada atau dengan kata lain kelas ini memiliki daya toleransi yang tinggi terhadap perubahan lingkungan. Hal ini sesuai dengan pernyataan Wulandari (2009) bahwa kelas Bacillariophyceae mampu menyesuaikan diri dengan lingkungan sekitarnya dibandingkan dengan kelas lainnya. Hal ini diperkuat oleh pernyataan Hutabarat (2013) bahwa kelas Bacillariophyceae mampu tumbuh dengan cepat meskipun pada kondisi nutrien dan cahaya yang rendah. Menurut Nurfadillah et al. (2012) kelas Bacillariophyceae merupakan jenis diatom yang paling toleran terhadap kondisi perairan seperti suhu dan mampu beradaptasi dengan baik pada lingkungan perairan, sehingga dapat berkembang biak dengan cepat yaitu tiga kali dalam 24 jam, serta dapat memanfaatkan kandungan nutrien dengan baik.

Pengukuran suhu di perairan Pulau Bokori pada saat pengukuran saat pengambilan sampel fitoplankton adalah $28-$ $30{ }^{\circ} \mathrm{C}$ dengan baku mutu perairan $25-30^{\circ} \mathrm{C}$ artinya biota masih dalam keadaan layak untuk hidup di perairan pulau Bokori.hal ini sesuai dengan pendapat Asih (2014) suhu optimum untuk pertumbuhan plankton berkisar antara $25-32{ }^{\circ} \mathrm{C}$, dengan demikian kondisi suhu perairan Pulau Bokori masih layak untuk kehidupan fitoplankton.

Berdasarkan hasil penelitian, fitoplankton yang didapatkan pada perairan Pulau Bokori terdiri dari 17 genera, ditemukan menyebar pada setiap stasiun pengamatan. Jumlah individu terbanyak yaitu Chaeteceros sp. (kelas Bacillariophyceae) yang didapatkan hampir di semua stasiun dan di setiap interval waktu pengambilan sampel, hal ini mengindikasikan bahwa fitoplankton jenis Chaeteceros sp. memiliki penyebaran yang sangat luas. Kelimpahan tertinggi berada pada kedalaman 0,5 meter yakni $1601 \mathrm{ind} / \mathrm{L}$ pada stasiun III, kelimpahan

Bacillariophyceae yang tertingi pada perairan Pulau Bokori diduga karena jenis ini mampu bertahan hidup pada saat cuaca berubah, kelimpahannya dipengaruhi oleh sifatnya yang kosmopolit (penyebarannya luas) umumnya pada perairan laut. Hal ini sesuai dengan pendapat Nontji (2008) bahwa kelimpahan dari kelas Bacillariophyceae dari golongan fitoplankton umunya masih tergolong berlimpah ditemukan di laut meskipun dalam kondisi cuaca yang berubahubah dan diperkuat oleh Abida (2010) bahwa genera fitoplankton dari kelas Bacillariophyceae ditemukan melimpah karena fitoplankton dari kelas tersebut merupakan anggota utama fitoplankton yang terdapat di seluruh bagian perairan laut, baik perairan pantai maupun perairan oseanik. 


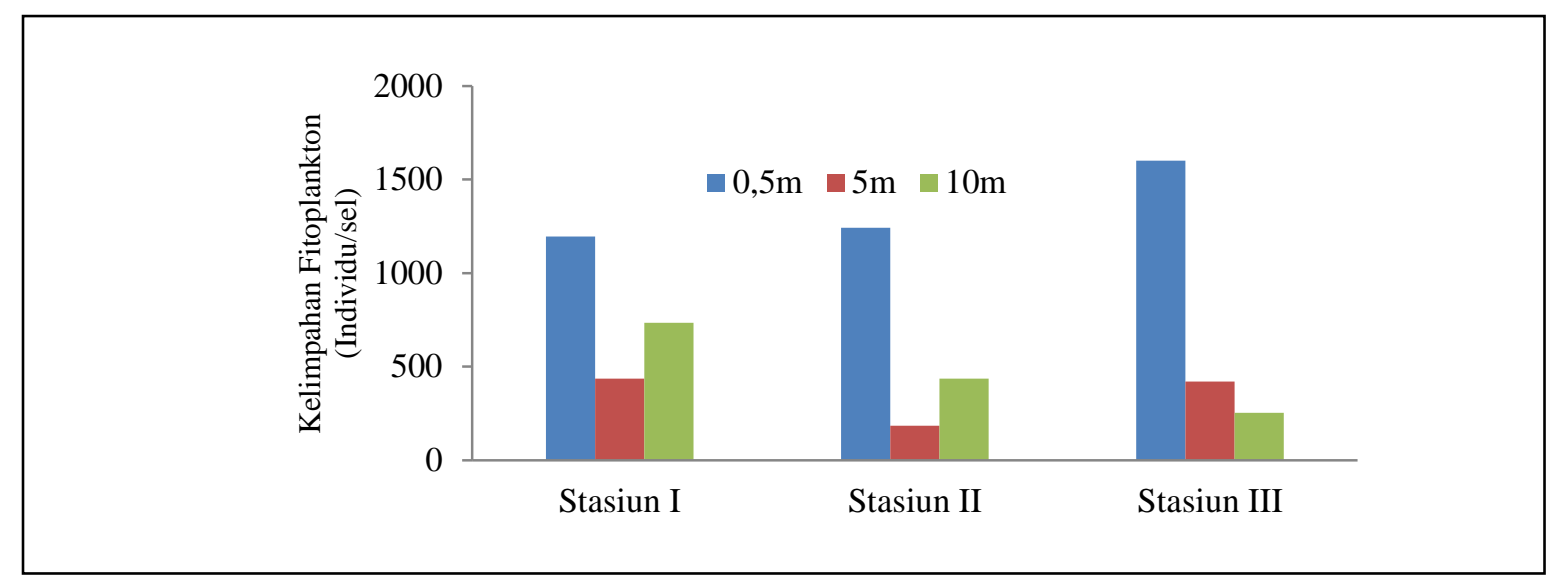

Gambar 5. Kelimpahan Fitoplankton di Perairan Pulau Bokori

Sedangkan nilai kelimpahan terendah berada pada kedalaman 5 meter yakni 185 ind/L pada stasiun II, rendahnya nilai kelimpahan pada kedalaman 5 meter disebabkan rendahnya penetrasi cahaya yang masuk ke dalam perairan. Rendahnya kecerahan suatu perairan akan menyebabkan nilai intensitas cahaya yang masuk ke dalam suatu perairan akan menurun sehingga dapat mempengaruhi kelimpahan fitoplankton, hal ini sesuai dengan pendapat Salwiyah (2010) kecerahan merupakan salah satu faktor pembatas bagi kehidupan fitoplankton karena mempengaruhi penetrasi cahaya yang masuk ke dalam perairan. Selain intensitas cahaya matahari, suhu perairan yang normal yaitu berkisar antara $28-30^{\circ} \mathrm{C}$ juga memengaruhi kelimpahan fitoplankton.hal ini sesuai dengan pernyataan Ambiasa (2007) bahwa suhu air yang baik bagi kelangsungan hidup dan perkembangan plankton berkisar antara 20 $30^{\circ} \mathrm{C}$. Menurut Manigasi (2013), suhu perairan memengaruhi keberadaan fitoplankton secara fisiologis dan ekologis. Secara fisiologis perbedaan suhu perairan sangat berpengaruh terhadap ukuran fitoplankton. Rendah kelimpahan fitoplankton pada stasiun II kedalaman 5 meter disebabkan oleh kecepatan arus yang rendah yakni $0,95 \mathrm{~m} / \mathrm{det}$. Hal ini didukung oleh Lasri dkk, (2013) menyatakan bahwa kecepatan arus merupakan parameter penting sehubungan dengan keberadaan fitoplankton, arus yang kencang dapat memengaruhi distribusi fitoplankton pada suatu perairan maka secara tidak langsung juga berpengaruh terhadap kelimpahan fitoplankton.

Tingginya nilai kelimpahan yang diperoleh pada stasiun III disebabkan oleh parameter-parameter lingkungan yang memengaruhi kehidupan dan perkembangan fitoplankton pada stasiun ini berada pada kisaran yang sesuai, suhu, kecerahan, kecepatan arus pada saat pengukuran didapatkan 1,075 $\mathrm{m} / \mathrm{det}$, kecepatan arus merupakan factor sebaran fitoplankton tidak merata di perairan Pulau Bokori. Menurut Wijayanti (2007) arus dari 0,1 m/det termasuk kecepatan arus yang sangat lemah, sedangkan kecepatan arus sebesar 0,1-1 m/det tergolong kecepatan arus yang sedang, dan kecepatan arus $>1 \mathrm{~m} /$ det tergolong kecepatan arus yang kuat. Dengan demikian kecepatan arus yang didapatkan di perairan Pulau Bokori di stasiun III merupakan kecepatan arus dalam keadaan tinggi. Intensitas cahaya matahari berada pada nilai yang optimal untuk mendukung kehidupan fitoplankton sedangkan kandungan nutrien bukan merupakan nilai yang optimum tetapi belum menjadi faktor pembatas bagi fitoplankton.

Berdasarkan nilai keanekaragaman yang diperoleh menunjukkan bahwa nilai keanekaragaman berada pada kategori rendah, hal ini sesuai dengan pendapat Odum (1998) yang menyatakan bahwa kisaran nilai indeks keanekaragaman $0-1$ menunjukkan bahwa daerah tersebut terdapat tekanan ekologis yang tinggi dan indeks keanekaragaman yang rendah dengan sebaran individu yang tidak merata dan kestabilan komunitas rendah. Semakin rendah atau melimpah fitoplankton maka akan semakin rendah atau melimpah pula keanekaragaman jenis fitoplankton dalam suatu perairan. Hal ini sesuai dengan pendapat Siagian (2012) yang mengatakan bahwa nilai kelimpahan rendah pada suatu komunitas maka tingkat indeks keanekaragamannya juga akan menurun karena keanekaragaman ditentukan oleh jumlah jenis dan jumlah individu dalam suatu komunitas. 
Tabel 2. Nilai Indeks Keanekaragaman(H'), Keseragaman (E) dan Dominansi (C) Fitoplankton di Perairan Pulau Bokori

\begin{tabular}{|c|c|c|c|c|c|c|c|c|c|}
\hline \multirow{3}{*}{ Kedalaman } & \multicolumn{9}{|c|}{ Indeks Biologi } \\
\hline & \multicolumn{3}{|c|}{$\begin{array}{c}\text { Keanekaragaman } \\
\left(\mathbf{H}^{\prime}\right)\end{array}$} & \multicolumn{3}{|c|}{$\begin{array}{c}\text { Keseragaman } \\
\text { (E) }\end{array}$} & \multicolumn{3}{|c|}{$\begin{array}{c}\text { Dominansi } \\
\text { (C) }\end{array}$} \\
\hline & $\mathrm{I}$ & II & III & $\mathrm{I}$ & II & III & $\mathrm{I}$ & II & III \\
\hline 0,5 meter & 0.068 & 0.112 & 0.084 & 0.038 & 0.058 & 0.042 & $0.980 *$ & 0.965 & 0.976 \\
\hline 5 meter & 0.121 & $0.396^{*}$ & 0.247 & 0.084 & $0.203 *$ & 0.114 & 0.956 & 0.850 & 0.920 \\
\hline 10 meter & 0.114 & 0.195 & 0.379 & 0.064 & 0.102 & 0.195 & 0.964 & 0.934 & 0.860 \\
\hline Kisaran & \multicolumn{3}{|c|}{$0.068-0.396$} & \multicolumn{3}{|c|}{$0.038-0.203$} & \multicolumn{3}{|c|}{$0.850-0.980$} \\
\hline \multicolumn{10}{|c|}{$\begin{array}{l}\text { Keterangan : I, II, III = Stasiun; E = Keseragaman; H’ = Keanekaragaman; C = Dominansi } \\
\qquad=\text { Nilai Tertinggi }\end{array}$} \\
\hline \multicolumn{10}{|c|}{ Tabel 3. Pola Distribusi Fitoplankton (Id) pada Lokasi Penelitian } \\
\hline \multicolumn{3}{|c|}{ Stasiun } & \multicolumn{4}{|c|}{ Pola Distribusi } & \multicolumn{3}{|c|}{ Kategori } \\
\hline \multicolumn{3}{|c|}{ I } & \multicolumn{3}{|c|}{2.919} & \multicolumn{4}{|c|}{ Mengelompok } \\
\hline \multicolumn{3}{|c|}{ II } & \multicolumn{3}{|c|}{2.838} & \multicolumn{4}{|c|}{ Mengelompok } \\
\hline \multicolumn{3}{|c|}{ III } & \multicolumn{3}{|c|}{2.845} & \multicolumn{4}{|c|}{ Mengelompok } \\
\hline
\end{tabular}

Berdasarkan nilai keseragaman yang diperoleh menunjukkan bahwa nilai keseragaman berada pada kategori tidak merata atau ada sekelompok jenis tertentu yang dominan. Hal ini sesuai pendapat Andi dan Burhanuddin (2015) yang mengatakan jika nilai $\mathrm{E}<0,4$, maka keseragaman berada pada kategori rendah, jika $0,4<\mathrm{E}<0,6$ maka keseragaman berada pada kategori sedang, dan jika $\mathrm{E}>0,6$ maka keseragaman berada pada tingkat yang tinggi. Tidak meratanya penyebaran individu fitoplankton pada perairan pulau Bokori diduga karena intensitas cahaya yang masuk kedalam perairan tidak cukup untuk kehidupan fitoplankton.

Berdasarkan hasil perhitungan yang dilakukan hal ini mengindikasikan bahwa dalam struktur komunitas fitoplankton pada perairan Pulau Bokori terdapat spesies yang mendominasi diantara spesies-spesies lain. Ada beberapa spesies yang tidak memiliki peluang untuk dapat tumbuh dan berkembang dengan baik. Hal ini menunjukkan bahwa kondisi struktur komunitas dalam keadaan tidak stabil, hal ini sesuia dengan pendapat Odum (1998) yang menyatakan bahwa bila nilai $\mathrm{C}$ mendekati $1(\geq 0,5)$ berarti di dalam struktur komunitas biota yang diamati terdapat spesies yang secara ekstrim mendominasi spesies-spesies yang lainnya. Jika kita melihat dari setiap stasiun dan setiap kedalaman pada penelitian ini, angka dominansi semua mendekati 1 sehingga dapat dijelaskan bahwa secara umum di perairan Pulau Bokori ada jenis fitoplankton yang mendominasi jenis lainnya selama penelitian ini berlangsung.

Berdasarkan perhitungan dengan menggunakan indeks morisita diperoleh nilai distribusi fitoplankton yakni 2,83 2,91. Hal ini menunjukkan bahwa distribusi jenis fitoplankton di lokasi penelitian cenderung mengelompok (id $>1,0$ ), artinya pola distribusi fitoplankton terjadi secara mengelompokpada ketiga stasiun penelitian. Pola distribusi mengelompok merupakan bentuk distribusi yang paling umum terjadi, karena individu-individu dalam populasi cenderung membentuk kelompok dalam berbagai ukuran. Hal ini sesuai dengan pernyataan Michael (1997) bahwa pola distribusi suatu organisme dipengaruhi oleh sifat fisika kimia yang mempengaruhi kehidupan dan distribusi fitoplankton di laut seperti suhu, cahaya matahari, kecerahan dan arus. Selain sifat-sifat fisika kimia perairan, distribusi juga dipengaruhi oleh daur pembiakan, tingkah laku spesies dalam populasi dan persaingan diantara spesies. 


\section{Simpulan}

Berdasarkan hasil perhitungan nilai indeks keanekaragaman ini menunjukkan bahwa nilai keanekaragaman fitoplankton diperairan Pulau Bokori termasuk rendah. Distribusi komunitas fitoplankton di perairan Pulau Bokori yaitu mengelompok.

\section{Daftar Pustaka}

Ambiasa, I.K. 2007. Distribusi Spasial Fitoplankton dan Zooplankton di Teluk Jakarta. Skripsi. Fakultas Perikanan dan Ilmu Kelautan IPB. Bogor: 80 hal.

APHA. 2005. Standar Methods for Examination of Water and Wastewater. New York.

Asih P. 2014. Produktivitas Primer Fitoplankton di Perairan Teluk Dalam Desa Malang Rapat Bintan. Skripsi. UMRAH FIKP: Tanjung Pinang.

Brower, J. E., J. H. Zar and C. von Ende. 1990. Ekologi Umum. Metode Lapangan dan Laboratorium. Wm. C. Brown Company Publisher, Dubuque, Lowa.

Fahrul, F.M. 2007. Metode Sampling Bioteknologi. Bumi Aksara. Jakarta.

Handayani, D. 2009. Kelimpahan dan Keanekaragaman Plankton di Perairan Pasang Surut Tambak Blanakan, Subang. Skripsi. Program Studi Biologi Fakultas Sains dan Teknologi, Universitas Islam Negri Syarif Hidayahtullah. Jakarta. 91. Hal.

Hutabarat, S dan S. M, Evans. 2013. Pengantar Oceanografi. Penerbit Universitas Indonesia (UI-Press). Jakarta. 159 hal.

Lasri, Desy, A., Endarwati, H., Santoso, G. W. 2013. Struktur Komunitas Plankton di Perairan Desa Mangurharjo Kecamatan Tugu Semarang. Jurnal of Marine Research. 2(3): 197- 204 hlm.

Madinawati. 2010. Kelimpahan Dan Keanekaragaman Plankton Di Perairan Laguna Desa Tolongano Kecamatan Banawa Selatan. Jurnal. VOL III (2):119123. Universitas Tadulako (UT): Sulawesi Tengah.

Michael, P. 1997. Metode Ekologi Untuk Penyelidikan Lapangan dan Laboratorium. (Alih Bahasa oleh Yanti R. Koestoer dan Suhati S.) Universitas Indonesia Press. Jakarta. 616 hal.

Nontji, A. 2008. Plankton Laut. Pusat Penelitian Oseanografi. Lembaga Ilmu Pengetahuan Indonesia (LIPI). LIPI Press.331 hal.
Nurfadillah, Damar A, Adiwilaga EM. 2012. Komunitas fitoplankton di perairan Danau Laut Tawar, Kabupaten Aceh Tengah, Provinsi Aceh. Depik. 1(2):9398.

Odum. 1998. Dasar-dasar Ekologi. Gajah Mada University Press. Edisi 3. Yogyakarta.

Patten, P., V. 2010. A Student's Guide to Common Phytoplankton of Long Island Sound. http://longislandsoundstudy.net

Pirzan, A.M., Utojo, M. Atmomarso, M. Tjaronge, A.M. Tangko, dan Hasnawi. 2005. Potensi lahan budi daya tambak dan laut di Kabupaten Minahasa, Sulawesi Utara. Jurnal Penelitian Perikanan Indonesia 11 (5): 43-50.

Salwiyah. 2010. Kondisi Kualitas Air Sehubungan Dengan Kesuburan Perairan Sekitar PLTU NII Tanasa Kabupaten Konawe Provinsi Sulawesi Tenggara. Warta-Wiptek. Vol. 18. No. 2. Hal: 5257.

Shannon, C.E., W. Wiener. 1949. The Mathematical Theory of Communication. University of Illinois Press. Urbanan.

Siagian, m. 2012. Jenis dan Keanekaragaman Fitoplankton di Waduk. Laboratorium Limnologi. Program Studi Manajemen Sumberdaya Perikanan Fakultas Perikanan dan Ilmu Kelautan Universitas Riau. Pekanbaru. Bumi Lstari, 7(1): 99105.

Wijayanti. 2007. Keanekaragaman Jenis Plankton Pada Tempat Yang Berbeda Kondisi Lingkungannya Di Rawa Pening Kabupaten Semarang. Skripsi. IKIP PGRI Semarang.

Wulandari, D. 2009. Keterikatan anntara Kelimpahan Fitoplankton dengan Parameter Fisika Kimia di Estuari Sungai Brantas (Porong), Jawa Timur. Skripsi. Departemen Manajemen Sumberdaya Perairan Fakultas Perikanan dan Ilmu Kelautan, Institut Pertanian. Bogor.

Yeanny MS. 2011. Komunitas fitoplankton sebagai bioindikator kualitas air sungai Belawan. Di dalam: Hutahean S, Ilyas S, Rahayu S, Berliani K, editor. Meningkatkan Peran Biologi dalam Mewujudkan National Achievement with Global Reach; 2011 Jan 22; Universitas Sumatera Utara, Indonesia. Medan (ID): USU Press. hlm 470-480. 